\title{
Measuring Tax Sensitivity of University Students*
}

\author{
Rüştü YAYAR**
}

\author{
Emin BARLAS ${ }^{* * *}$
}

\author{
Gökhan GÜNEY****
}

\begin{abstract}
Tax compliance has become the main issue for all taxation authorities. Tax sensitivity, tax consciousness and tax awareness plays very important role in increasing tax revenues by increasing the level of tax compliance. Understanding and measuring of those factors is very important to generate more tax revenue and serving more public services. Tax sensitivity and tax consciousness of citizens are not only related to external variables such as tax rate, income and probability of audits and severity of fines, but also related to internal variables, such as citizens' knowledge of tax law, their attitudes towards the government and taxation, personal norms, perceived social norms. This study aimed to understand the perspective of university students for tax sensitivity. For this purpose, tax sensitivity levels of senior students of Tokat Gaziosmanpaşa University Faculty of Economics and Administrative Sciences were investigated. A total of 290 students' tax sensitivity level was surveyed using questionnaire survey. Factor analysis, One-way ANOVA and independent sample t tests were used in the study.
\end{abstract} Compliance.

Keywords: Tax Sensitivity, Tax Consciousness, Tax Awareness, Tax Avoidance, Tax

JEL Classification: C83, $H 26$.

\section{Üniversite Öğrencilerinin Vergi Duyarlılıklarının Ölçülmesi}

$\ddot{O} Z$

Vergi uyumu tüm vergilendirme otoritelerinin ana konusu haline gelmiştir. Vergi duyarlılı̆̆l, vergi bilinci ve vergi farkındalı̆̆l; vergi uyum düzeyini artırarak vergi gelirlerinin artırılmasında çok önemli bir rol oynamaktadır. Bu faktörlerin anlaşılması ve ölçülmesi daha fazla vergi geliri elde edilmesi ve daha fazla kamu hizmeti sunulması açısından fazlaca önem taşımaktadır. Vatandaşların vergi duyarlılı̆̆l ve vergi bilinci sadece vergi oranı, gelir ve denetim olasılığ ve cezaların şiddeti gibi dışsal değişskenlerle değil, aynı zamanda vatandaşların vergi kanunu bilgisi, hükümete ve vergilendirmeye karşı tutumları, kişisel normlar ve algılanan sosyal kurallar gibi iç değişkenlerle de ilgilidir. Bu çalışma, üniversite öğrencilerinin vergi duyarlıllğ konusundaki bakış açılarını kavramayı amaçlamıştır. Bu amaçla Gaziosmanpaşa Üniversitesi İktisadi ve İdari Bilimler Fakültesi son sınıf ögrencilerinin vergi duyarlılık düzeyleri incelenmiştir. Anket uygulaması yapılarak toplam 290 öğrencinin vergi duyarlılı̆̆ düzeyi araştırılmıştır. Çalışmada faktör analizi, tek yönlü ANOVA ve bağımsız örneklem t testleri kullanılmıştır.

Anahtar Kelimeler: Vergi Duyarlılı̆̆ı, Vergi Bilinci, Vergi Farkındalı̆̆̆, Vergiden Kaçınma, Vergi Uyumu.

JEL Siniflandırması:C83, H26.

\footnotetext{
* This study was presented as oral presentation in International Congress on Political, Economic and Social Studies (ICPESS) 19-22 May, 2017, Sarajevo / Bosnia Herzegovina.

** Assoc. Prof. Dr. Tokat Gaziosmanpaşa University, Faculty of Economics and Business Administration, Department of Economics, rustu.yayar@gop.edu.tr

*** Assist. Prof. Dr. Tokat Gaziosmanpaşa University, Faculty of Economics and Business Administration, Department of Public Finance, emin.barlas@gop.edu.tr

**** Tokat Gaziosmanpaşa University, Faculty of Economics and Business Administration, Department of Public Finance, Master Student, gokhan.gny4216@gop.edu.tr
} 


\section{INTRODUCTION}

Government expenditures have been rising for decades. It represented $40.9 \%$ of GDP on average across OECD countries in 2015. This level of expenditure was $38.8 \%$ in 2007 (OECD, 2017: 74).

In an environment where public spending is constantly increasing, revenues have become more important than ever. Taxes are most important revenue element of state budgets. For example in 2016, the share of tax revenues in general budget revenues was $87 \%$ in Turkey (Muhasebat Genel Müdürlüğü, 2017).

While public expenditure increase is continuing, the loss and evasion of taxes make it difficult to generate tax revenues and to finance public expenditures. If revenues are lower than public expenditure budget deficit becomes. This situation causes the state to borrow. Voluntary compliance of taxpayers is vital to collect taxes adequately and timely. The importance of tax consciousness arises at this point. Tax consciousness ensures that taxpayers pay their taxes in a timely and meticulous manner. Timely and meticulous payments reduce the audit burden of tax administrations. The formation of tax consciousness, on the other hand, allows taxpayers to question expenditure of their governments. They start to expect more from the government. Taxpayers become more conscious individuals. In countries where tax consciousness is not sufficiently developed, the tax is seen as a burden, and taxpayers avoid paying taxes. As a result, tax revenue is adversely affected (Güner, 2008: 7-8).

Tax consciousness plays very important role in increasing tax revenues by increasing the level of tax compliance. Today, many studies were carried out to increase taxpayer compliance level. It has been understood that effective taxation cannot be carried out only with frequently changed legislation. The importance of increasing level of awareness of taxpayers has begun to be emphasized (Hasseldine and Hite, 2003: 529). There is a direct correlation between tax consciousness and voluntary compliance. The level of tax compliance is increasing in the countries where taxes are properly spent and quality public services are provided. Thus, the tax payments will not be seen as a burden for the taxpayer. The taxpayer who receives equivalent public services of the paid taxes will not be in negative behaviours towards tax (Csontos et al., 1998: 288).

Taxpayers' willingness to cooperate with the state and its institutions and to pay taxes depends on a variety of variables. While economists stress the relevance of external variables such as tax rate, income and probability of audits and severity of fines, psychological research shows that internal variables, such as Citizens' knowledge of tax law, their attitudes towards the government and taxation, personal norms, perceived social norms and fairness are of similar importance (Hofmann et al. 2008). In addition, one of the taxpayers' prejudiced approaches, the use of taxation on tax consciousness cannot be denied. Because taxpayers' recognition of the beneficial use of paid taxes will increase tax compliance (Torgler et al., 2008: 2). 
Tax administrations are seeking to improve the level of tax compliance among taxpayers which in turn will increase the figures of tax revenue in the national budget. This required developing the level of awareness of tax (tax education \& tax knowledge) amongst taxpayers and providing all possible information to taxpayers (Palil et al., 2016).

The behaviour of taxpayers towards taxation shows how taxpayers perceive tax. Knowing why paying taxes in the well-conceived society will lead to a change in the positive direction of the taxation behaviour of taxpayers (Maciejovsky et al., 2007: 689). However, taxpayer consciousness is important not only in taxpayers but also in the government. Approach and implementation of tax administrations and tax consciousness of their employees will lead to the formation of tax consciousness in the whole society (Torgler, 2004: 4). Modern taxation systems rely on self-assessment system. The system requires tax payers to do calculation, payment, and reporting their own tax payable by themselves. In this system, simplified taxation procedures encourage taxpayers to comply tax liabilities. For example; tax returns are filled and given by taxpayers. In this systems tax consciousness of citizens is key factor of success. The basic condition of a successful taxation depends on the development of taxpayers' tax consciousness (Sürmen, 1992: 26-27).

It is important to evaluate taxpayers' sensitivity to taxation in the development of tax consciousness. Taxpayers' psychological assessments to taxation have an important role in the success of fiscal and extra-fiscal goals of taxation policies. The attitude of the individual towards taxation also reflects the attitude of the society. Tax consciousness and the positive tax sensitivity to taxations are also of great importance in terms of achieving optimal tax revenue (Hazman, 2009: 54).

Tax consciousness has great importance for the state in terms of authority and continuity. Therefore, it is necessary to increase the citizens' tax consciousness levels. In order to achieve this, an appropriate and effective education on tax awareness and consciousness is required. Otherwise, negative situations such as tax evasion and decrease in tax revenues can occur (Egeli and Diril, 2014: 36).

Finally, individuals also benefit from the settlement of tax consciousness. Approaches and practices that are not adopted by society will not be permanent. Tax consciousness must be given that the full fulfilment of tax duties is a good citizenship. Tax loss and evasion not be prevented unless education of new generations and the tax consciousness to be established in this training process are understood. Besides this, the informal economy cannot be recorded (Buyrukoğlu and Erasa, 2012: 122). For tax education it is important that students should know that tax is important therefore they need to learn since it is unavoidable onus (Hastuti, 2014).

\section{CONCEPTUAL FRAMEWORK}

In this study, main concepts are tax consciousness, tax awareness and tax sensitivity. In the literature, there is no consensus on these concepts. At the same 
time, these concepts are close to each other and sometimes used in place of each other. For this reason we will try to include elements and different definitions of these concepts.

Above all, the concept of tax consciousness itself is uncertain. In the taxation literature, the term "tax consciousness" generally refers to the public's response to the implementation of tax obligations. Tax consciousness can be defined as "the responses of the taxpayers both in their consent, resistance, and habits of compliance, and on the impact of tax measures on the whole complex of economic motivation" (Kintanar, 1964: 24).

Akdoğan defines tax conscious as follows: "The tax consciousness is level of citizens' willingness to fulfil tax duties that are aware of the importance of taxation in the realization of public services" (Akdoğan, 2003: 180).

The tax consciousness is also defined as the internal motivation of the taxpayers on paying taxes (Torgler, 2005: 526; Hazman, 2009: 54).

Narta defines tax consciousness as follows: "Citizens must have the ability to recognize, know and remember that they must make contributions in accordance with the procedures, principles and rates laid down by law in the income or wealth of the citizens, in order to provide the public expenditure that the state is obliged to fulfill" (Güner, 2008: 5).

Tax consciousness should not be perceived as only tax payments of taxpayers. It should also be considered questioning of political power for public expenditures which are financed by taxes (Ömürbek et al., 2007: 104). If the government spent taxes on the right public services the loyalty of citizens to state will increase. These encourage citizens' willingness to fulfil their tax obligations voluntarily (Yeşilyurt, 2015: 39). The voluntary fulfillment of mandatory obligations by taxpayers is of great importance for the collection of tax revenues and the fulfilment of other purposes that is, for the system to function better (Aktan, 1997: 11).

Although there is no common definition for tax consciousness the basic emphasis on the concept is that taxpayers are well aware of the importance of the taxes for public services and taxpayers' perception to taxation is positive.

The tax awareness means that individuals follow tax legislation and legislative changes or whether they have sufficient information on taxation. Citizens also aware that the taxes are reason for financing of public service expenditure (Buyrukoğlu and Erasa, 2012:121).

Table 1: Factors Affecting the Formation of Tax Consciousness

\begin{tabular}{|l|l|}
\hline Personal Factors & Environmental Factors \\
\hline Demographic Characteristics & Tax Justice \\
\hline Efficiency of Tax Payment Power & $\begin{array}{l}\text { Extension of the Amendment to the } \\
\text { Tax Legislation }\end{array}$ \\
\hline Tax Moral & Tax Rates \\
\hline Subjective Tax Burden & Tax Amnesty \\
\hline Education and Training Level of Taxpayer & Efficiency of Tax Penalties \\
\hline Loyalty of Taxpayer to State & Efficiency of Tax audits \\
\hline
\end{tabular}




\begin{tabular}{|l|l|}
\hline Taxpayer' Thoughts about the obligatory political power & Efficiency of Tax Administration \\
\hline Income Level of Taxpayer & \\
\hline Viewpoint of Taxpayers to the Other Taxpayers & \\
\hline Taxpayers' Views on Public Expenditures & \\
\hline
\end{tabular}

Note: Table 1 was compiled from Alkan (2009) master thesis.

\section{MATERIAL AND METHOD}

Primary and secondary data had been used in this study. Primary data were provided with senior students of Tokat Gaziosmanpaşa University Faculty of Economics and Administrative Sciences. The size of the sample that can represent senior students was determined as 290 . The number of questionnaires to be made was determined proportionate to the total number of participants. Questionnaires were randomly selected students. Surveys were conducted by face-to-face interview method. In the survey, the 19-questions form was used to measure the tax sensitivity of university students with five Point Likert-type scales. For measuring either positive or negative response from statement five pre-coded responses were given in the form. These are;

-Strongly disagree (1),

-Disagree (2),

-Undecided (3),

-Agree (4) and

-Strongly agree (5).

The questionnaire form used in this study was also used in the study of Ömürbek et al. (2007) with name of "An Analysis on Tax Consciousness: The Findings of the Survey on University Students."

Frequency, factor and variance analysis were performed by using SPSS 16.0 package program. As a result of the factor analysis, it was determined that the tax sensitivity was added to five sub-dimensions. At a later stage, these subdimensions were tested by independent sample t-test, which showed differences according to gender, average income, divisions, regions and additional work, and one-way analysis of variance (ANOVA) for more than two independent groups.

The variance analysis, a decision-making technique developed by the British statistician Ronald Aylmer Fischer, was developed in order to determine whether the total variability of the two variables is meaningfully different by dividing them into sources of variability. Since it was developed by Fischer, it has been named "F test" (Özkan, 2007:234).

Independent samples t-test is a method for determining whether the averages of two independent groups are different from each other. At the point of testability, the groups to be compared must be independent from each other and the measurements obtained from the groups must be measured at least at the same level of the interval scale (Durmuş et al., 2010: 118).

In practice the t-test in allows only two groups to compare the differences between the groups. One-way ANOVA is the test statistic that should be applied if there are more groups. The one-way ANOVA test can be used to make binary comparisons of the groups in addition to the ANOVA test, and if there is a 
difference between the groups, information on the source of this difference can be obtained, but nothing can be said about the source of the difference in the ANOVA test (Altunışık et al., 2010: 199-201).

\section{RESEARCH FINDINGS}

Firstly, factor analysis was performed to determine the tax sensitivities of the students and the percentages of the eigenvalues of the factors and the explained variances are given in Table 2 . The explanatory expressions, as seen in the table, are based on 5 factors. It was determined that the factor with the highest variance was 3.940 and the variance explained 21.888, the second factor was 2.170 , and the variance explained was 12.054. The total variance of the five factors is 54.837. According to Kline (1994), it is difficult to reach a high percentage of explanations in terms of social sciences. Therefore, it is stated that $40 \%$ explanatory is a good rate.

Descriptive statistics on the results of factor analysis and items are presented in Table 3. Initially, factor analysis that applied on nineteen items, then only one item was removed from the scale and 18 items were used in the last case. Thus, the explanatory variance has increased. As a result of the conducted factor analysis, it was determined that the scale had a five sub-dimensional structure.

Table 2: Eigenvalues of the Factors and Percentage of the Explained Variances

\begin{tabular}{lcccccc}
\hline \multirow{2}{*}{ Component } & \multicolumn{3}{c}{ Initial Eigenvalues } & \multicolumn{3}{c}{ Rotation Sums of Squared Loadings } \\
\cline { 2 - 7 } & Total & \% of Variance & $\begin{array}{c}\text { Cumulative } \\
\text { \% }\end{array}$ & Total & \% of Variance & $\begin{array}{c}\text { Cumulative } \\
\text { \% }\end{array}$ \\
\cline { 2 - 7 } 1 & 3.940 & 21,888 & 21.888 & 3.475 & 19.305 & 19.305 \\
2 & 2.170 & 12.054 & 33.941 & 1.897 & 10.537 & 29.843 \\
3 & 1.519 & 8.441 & 42.382 & 1.618 & 8.988 & 38.830 \\
4 & 1.185 & 6.581 & 48.963 & 1.452 & 8.066 & 46.896 \\
5 & 1.057 & 5.874 & 54.837 & 1.429 & 7.940 & 54.837 \\
\hline
\end{tabular}

They are: Tax consciousness, tax awareness, tax avoidance, tax resistance and knowing the tax system. The reliability of the 18 items used was also measured by Cronbach Alpha and the general reliability was calculated as $\alpha=0.718$. If this value is greater than 0.70, it shows suitability (Altunışık et al., 2015: 114).

Table 3: Descriptive Statistics of the Items and Rotated Factor Load Values

\begin{tabular}{|c|c|c|c|}
\hline Articles & Mean & Std. Deviation & Factor Loads \\
\hline Tax Consciousness $\quad(\alpha=0.830)$ & $\mu=3.8224$ & & \\
\hline Tax is a part of social responsibility. & 3.8897 & 1.04645 & 0.815 \\
\hline Tax is a holy civic duty. & 3.8103 & 1.04661 & 0.789 \\
\hline $\begin{array}{l}\text { Unpaid taxes today increase the tax and debt burden of next } \\
\text { generations. }\end{array}$ & 3.8724 & 1.07227 & 0.703 \\
\hline Taxation is a legal issue. & 3.9966 & .92448 & 0.678 \\
\hline Taxation is a moral issue. & 3.6241 & 1.07187 & 0.591 \\
\hline $\begin{array}{l}\text { If I do not pay the tax in full and correctly, the state services } \\
\text { will hinder. }\end{array}$ & 3.7414 & 1.05490 & 0.665 \\
\hline $\begin{array}{ll}\text { Tax Awareness } & (\alpha=0.583)\end{array}$ & $\mu=2.9198$ & & \\
\hline I am aware of all the taxes I pay as a taxpayer. & 3.3483 & 1.01855 & 0.548 \\
\hline I have enough information about tax legislation. & 2.8414 & .94978 & 0.707 \\
\hline I believe that the taxes we pay are used by the state properly. & 2.8828 & 1.13457 & 0.677 \\
\hline There is a fair taxation system in Turkey. & 2.6069 & 1.13635 & 0.688 \\
\hline $\begin{array}{ll}\text { Tax Avoidance } \quad(\alpha=0.492)\end{array}$ & $\mu=3.4345$ & & \\
\hline As the tax burden is high, the informality is big. & 3.5759 & 1.03374 & 0.580 \\
\hline $\begin{array}{l}\text { The state cannot collect sufficient tax revenue because the } \\
\text { tax rates are high. }\end{array}$ & 3.3069 & 1.11251 & 0.700 \\
\hline Corruption news causes tax avoidance & 3.4207 & 1.07291 & 0.640 \\
\hline
\end{tabular}




\begin{tabular}{lccc}
\hline Tax resistance $(\boldsymbol{\alpha}=\mathbf{0 . 4 2 7})$ & $\boldsymbol{\mu}=\mathbf{3 . 5 1 8 4}$ & & \multirow{2}{*}{0.638} \\
$\begin{array}{l}\text { I question in the ballot box how and where the taxes which I } \\
\text { paid were spent }\end{array}$ & 3.3759 & 1.13764 & 0.577 \\
$\begin{array}{l}\text { Tax amnesties encourage non-fulfilment of tax duties. } \\
\text { I feel very embarrassed if I evade the tax and my }\end{array}$ & 3.4655 & 1.22284 & 0.628 \\
acquaintances learn the situation & $\boldsymbol{\mu}=\mathbf{3 . 1 8 7 9}$ & & 0.7138 \\
\hline $\begin{array}{l}\text { Knowing the Tax system }(\boldsymbol{\alpha}=\mathbf{0 . 4 1 8}) \\
\text { Turkish tax legislation is very complex and difficult to }\end{array}$ & 3.4034 & 1.04202 & 0.631 \\
$\begin{array}{l}\text { understand. } \\
\text { Tax is a barrier to private investments. }\end{array}$
\end{tabular}

Extraction Method: Basic Components. Rotation Method: Varimax

As can be seen in Table 3, the factor loads of tax consciousness are between 0.591 and 0.815 , the factor loads of tax awareness are between 0.548 and 0.707, the factor loads of tax avoidance are between 0.580 and 0.700 , the factor loads of tax resistance are between 0.577 and 0.638 , and finally the factor loads of knowing the tax system it ranges from 0.631 to 0.710 .

Whether or not the tax sensitivity differs according to the socio-economic and demographic characteristics of the students is statistically investigated. For this purpose; attributes related to participation are given in Table 4 and variance analysis according to the characteristics mentioned in Table 5.

Table 4: Socio-Economic and Demographic Characteristics of Participants

\begin{tabular}{lrr}
\hline & Frequency & $\%$ \\
\hline Departments & & \\
\hline Economics & 80 & 27.6 \\
Business & 80 & 27.6 \\
Public Finance & 49 & 16.9 \\
Public Administration & 81 & 27.9 \\
Gender & & \\
\hline Male & 194 & 66.9 \\
Female & 96 & 33.1 \\
Regions & & \\
\hline Marmara & 39 & 13.4 \\
Aegean & 10 & 3.4 \\
Anatolia & 74 & 25.5 \\
Black sea & 116 & 40.0 \\
Mediterranean & 22 & 7.6 \\
Eastern Anatolia & 15 & 5.2 \\
South eastern Anatolia & 14 & 4.8 \\
Average Monthly Income (TL) & & \\
\hline $0-500$ & 117 & 40.3 \\
500-1000 & 130 & 44.8 \\
1000-1500 & 28 & 9.7 \\
E00 and over & 15 & 5.2 \\
Employment Status (Have Job) & & \\
\hline No & 270 & 93.1 \\
Yes & 20 & 6.9 \\
\hline
\end{tabular}

While $16.9 \%$ of the participants were in the finance section, the proportion of the participants from each other section was $27.6 \%$. It is seen that the participant students consisted mostly of students who resided in the Black Sea region (40\%) and at least in the Aegean region (10\%). In terms of the gender of participants, female students (66.9\%) were twice as many as male students (33\%). Twenty (6.9\%) of the students who applied the survey have a job. The number of students with income between 500-1000 TL is 130 (44.8\%) and it has the highest rate; the number of those who have $1500 \mathrm{TL}$ and over income is $15(5.2 \%)$ with lowest rate. 
Table 5: Results of Analysis on Sub-Dimensions of Tax Sensitivity by Various Variables

\begin{tabular}{|c|c|c|c|c|c|c|c|c|c|c|}
\hline \multirow[b]{3}{*}{ Departments } & \multicolumn{2}{|c|}{ Tax Consciousness } & \multicolumn{2}{|c|}{$\begin{array}{r}\text { Tax } \\
\text { Awareness } \\
\end{array}$} & \multicolumn{2}{|c|}{$\begin{array}{r}\text { Tax } \\
\text { Avoidance }\end{array}$} & \multicolumn{2}{|c|}{ Tax Resistance } & \multicolumn{2}{|c|}{$\begin{array}{r}\text { Knowing the Tax } \\
\text { System }\end{array}$} \\
\hline & \multicolumn{2}{|c|}{$\begin{array}{r}\text { Std. } \\
\text { Mean Deviation }\end{array}$} & \multicolumn{2}{|c|}{$\begin{array}{r}\text { Std. } \\
\text { Mean Deviation }\end{array}$} & \multicolumn{2}{|c|}{$\begin{array}{r}\text { Std. } \\
\text { Mean Deviation }\end{array}$} & \multicolumn{2}{|c|}{$\begin{array}{r}\text { Std. } \\
\text { Mean Deviation }\end{array}$} & \multicolumn{2}{|c|}{$\begin{array}{r}\text { Std. } \\
\text { Mean Deviation } \\
\end{array}$} \\
\hline & & & & & & & & & & \\
\hline Economics & 3.6292 & .87671 & 2.9031 & .80789 & 3.5167 & .76657 & 3.4583 & .90066 & 3.3000 & .77378 \\
\hline Business & 3.8813 & .63931 & 3.0375 & .71279 & 3.3708 & .71156 & 3.4125 & .78531 & 3.2125 & .74534 \\
\hline Public Finance & 4.3605 & 1.14076 & 2.9949 & 63017 & 3.4218 & .76913 & 3.8231 & .70416 & 3.0714 & .81650 \\
\hline $\begin{array}{l}\text { Public } \\
\text { Administration }\end{array}$ & 3.7840 & .80210 & 2.7747 & .70888 & 3.4239 & .78707 & 3.4979 & .76399 & 3.1235 & .91355 \\
\hline \multirow[t]{2}{*}{ Total } & 3.8655 & .88035 & 2.9198 & .73015 & 3.4345 & .75619 & 3.5184 & .80884 & 3.1879 & .81510 \\
\hline & $F=7.848$ & $P=.000$ & $\mathrm{~F}=1.966$ & $\mathrm{P}=.119$ & $\mathrm{~F}=.511$ & $\mathrm{P}=.675$ & $F=3.001$ & $P=.031$ & $\mathrm{~F}=1.031$ & $\mathrm{P}=.379$ \\
\hline \multicolumn{11}{|l|}{ Regions } \\
\hline Marmara & 3.9060 & 1.06910 & 2.6538 & .59498 & 3.4017 & .78799 & 3.4615 & .83985 & 3.1282 & .77560 \\
\hline Aegean & 3.3833 & .88209 & 2.8750 & .95197 & 3.06 & .84327 & 4.06 & .79815 & 3.4 & .84327 \\
\hline Anatolia & 3.9887 & .66170 & 3.1216 & .70740 & 3.4955 & .77291 & 3.5991 & .70220 & 3.1757 & .88144 \\
\hline Black sea & 3.8089 & .82861 & 2.8858 & .77136 & 3.4511 & .72532 & 3.4483 & .80109 & 3.2241 & .80850 \\
\hline Mediterranean & 3.9091 & 1.29685 & 2.6932 & .59227 & 3.4242 & .85562 & 3.4697 & 1.06239 & 2.9091 & .75018 \\
\hline $\begin{array}{l}\text { Eastern } \\
\text { Anatolia }\end{array}$ & 3.8222 & .91171 & 3.0833 & .69864 & 3.3111 & .72885 & 3.6000 & .81844 & 3.2333 & .65101 \\
\hline $\begin{array}{l}\text { South eastern } \\
\text { Anatolia }\end{array}$ & 3.8929 & .94870 & 3.0893 & .64753 & 3.4762 & .70060 & 3.4286 & .84153 & 3.3571 & .88641 \\
\hline \multirow[t]{2}{*}{ Total } & 3.8655 & .88035 & 2.9198 & .73015 & 3.4345 & .75619 & 3.5184 & .80884 & 3.1879 & .81510 \\
\hline & $\mathrm{F}=.850$ & $\mathrm{P}=.532$ & $F=2.536$ & $P=.021$ & $F=.565$ & $\mathrm{P}=.758$ & $\mathrm{~F}=1.137$ & $\mathrm{P}=.341$ & $\mathrm{~F}=.722$ & $\mathrm{P}=.632$ \\
\hline \multicolumn{11}{|l|}{ Income (TL) } \\
\hline $0-500$ & 3.9373 & 1.00899 & 2.7778 & .69696 & 3.4815 & .73297 & 3.4729 & .75333 & 3.1581 & .82171 \\
\hline $500-1000$ & 3.8474 & .72039 & 2.9750 & .75280 & 3.4077 & .78888 & 3.5564 & .84693 & 3.2115 & .81141 \\
\hline $1000-1500$ & 3.9286 & .94546 & 3.2232 & .72756 & 3.4762 & .66931 & 3.6548 & .85818 & 3.1071 & .80917 \\
\hline 1500 and over & 3.3444 & .84390 & 2.9833 & .59362 & 3.2222 & .82295 & 3.2889 & .80541 & 3.3667 & .85496 \\
\hline \multirow[t]{2}{*}{ Total } & 3.8655 & .88035 & 2.9198 & .73015 & 3.4345 & .75619 & 3.5184 & .80884 & 3.1879 & .81510 \\
\hline & $\mathrm{F}=2.101$ & $\mathrm{P}=.100$ & $\mathrm{~F}=\mathbf{3 . 4 5 9}$ & $P=.017$ & $\mathrm{~F}=.625$ & $\mathrm{P}=.599$ & $\mathrm{~F}=.886$ & $\mathrm{P}=.449$ & $\mathrm{~F}=.418$ & $\mathrm{P}=.740$ \\
\hline \multicolumn{11}{|l|}{ Gender } \\
\hline Female & 3.9184 & .88293 & 2.8570 & .68607 & 3.4038 & .70132 & 3.4089 & .77676 & 3.1985 & .79052 \\
\hline \multirow[t]{2}{*}{ Male } & 3.7587 & .86986 & 3.0469 & .80075 & 3.4965 & .85702 & 3.7396 & .83098 & 3.1667 & .86653 \\
\hline & $\mathrm{t}=1.457$ & $\mathrm{p}=.146$ & $t=-2.097$ & $p=.037$ & $\mathrm{t}=-.919$ & $\mathrm{p}=.360$ & $t=-3.333$ & $p=.001$ & $\mathrm{t}=.312$ & $\mathrm{p}=.755$ \\
\hline \multicolumn{11}{|l|}{$\begin{array}{l}\text { Employment } \\
\text { status }\end{array}$} \\
\hline No & 3.8679 & .88006 & 2.9000 & .71540 & 3.4432 & .75271 & 3.5148 & .80810 & 3.2148 & .79972 \\
\hline Yes & 3.8333 & .90644 & 3.1875 & .88435 & 3.3167 & .81273 & 3.5667 & .83841 & 2.8250 & .94972 \\
\hline & $t=.169$ & $\mathrm{p}=.866$ & $\mathrm{t}=.147$ & $\mathrm{p}=.089$ & $\mathrm{t}=.722$ & $\mathrm{p}=.471$ & $\mathrm{t}=-.276$ & $\mathrm{p}=.783$ & $t=.455$ & $p=.039$ \\
\hline
\end{tabular}

Sub-dimension of tax sensitivity was analysed in terms of whether they are statistically significant according to participants' departments, regions, gender, employment and income status. The results of analysis are shown in Table 5.

The one-way analysis of variance (ANOVA) used to investigate whether tax sensitivity, tax consciousness, tax awareness, tax avoidance, tax resistance and level of knowledge of the tax system of students differed according to department that they have studied. According to the results of the study, the levels of tax consciousness and resistance to taxation were statistically meaningful $(\mathrm{P}=0.000$ and $\mathrm{P}<0.05$ and $\mathrm{P}=0.031$ respectively, $\mathrm{P}<0.05)$. As a result of the Scheffe Test 
conducted to determine the differences between the departments, it was determined that there are meaningful differences between public finance and the other departments in terms of tax awareness, and also in terms of tax resistance only between the public finance department and the business department. According to these results, it can be said that the level of tax consciousness of the students of the public finance department is relatively higher than the students of the other departments.

When examining whether the sub-dimensions of tax sensitivity are meaningfully different according to the regions where university senior students live, there is only a meaningful difference in terms of tax awareness. But it could not be determined that in which two regions have meaningful difference in terms of tax awareness. No meaningful difference was found in the other factors.

It was also examined whether tax sensitivity of students differed meaningfully according to income level of participants. According to results, there was only a meaningful difference in tax awareness and no meaningful difference was observed in the other factors. According to the Scheffe Test, there is a meaningful relationship between the income group of 500-1000 TL and the income group of $0-500 \mathrm{TL}(\mathrm{P}=0.037, \mathrm{P}<0.05)$. Among the income groups, it is seen that the average of university students who earned 500-1000 TL income (2.9750) are higher tax sensitivity than the students who earned TL 0-500 (2.7778).

According to survey results, a meaningful difference was found in tax awareness and tax resistance in terms of gender of participants. But no meaningful difference was found in the other factors. In terms of tax awareness, the awareness of male students (3.04) was higher than awareness of female students (2.85). It was determined that the average of tax resistance of male students (3.73) was higher than that of female students (3.40).

When we examine the sub-dimensions of tax sensitivity in terms of the participants' working status, it is seen that only knowing the tax system has a meaningful difference. There is no meaningful difference in the other factors. It was found that students who do not work (3.21) have more knowledge about the tax system than the working students (2.82).

\section{CONCLUSION AND EVALUATION}

The objective of this survey is to measure the tax sensitivities of university students. In the survey, the 19-question form was used to measure the tax sensitivity of university students with five Point Likert-type scales. The main finding of the Survey is that the tax sensitivities of university students differ according to the socio-economic characteristics of the students. Survey findings as below:

It has been observed that departments of students cause the differences in the tax consciousness and the resistance to the taxation. It was determined that there are meaningful differences between public finance and the other departments in terms of tax awareness, and also in terms of tax resistance only between the public finance department and the business department. 
Another finding of the Survey is that there is a meaningful difference in terms of tax awareness according to the region where the students live. But it could not be determined that in which two regions have meaningful difference in terms of tax awareness. No meaningful difference was found in the other factors.

It was also examined whether tax sensitivity of students differed meaningfully according to income level of participants. According to results, there was only a meaningful difference in tax awareness and no meaningful difference was observed in the other factors. Among the income groups, it is seen that the average of university students who earned 500-1000 TL income are higher tax sensitivity than the students who earned TL 0-500.

According to survey results a meaningful difference was found in tax awareness and tax resistance in terms of gender of participants. But no meaningful difference was found in the other factors.

When we examine the sub-dimensions of tax sensitivity in terms of the participants' working status, it is seen that only knowing the tax system has a meaningful difference. There is no meaningful difference in the other factors. It was found that students who do not work have more knowledge about the tax system than the working students.

\section{REFERENCES}

Altunışık, R., Coşkun, R., Bayraktaroğlu, S. ve Yıldırım, E. (2005). Sosyal Bilimlerde Araştırma Yöntemleri: SPSS Uygulamalı, 4. bask1, Sakarya: Sakarya Kitabevi.

Akdoğan, A. (2003). Kamu Maliyesi, Ankara: Gazi Kitabevi.

Aktan, H.B. (1997). Toplumda Vergi Bilinci, Vergi Kültürü ve Vergi Ahlakının Önemi, Yaklaşım Dergisi, Cilt:5, Sayı: 2

Alkan, A. (2009). Vergi Bilinci ve Vergi Uygulamaları Karşısında Mükellef Davranışlarının Tespiti: Zonguldak İli Örneği, Karaelmas Üniversitesi Sosyal Bilimler Enstitüsü, (Yayınlanmamış Yüksek Lisans Tezi), Zonguldak.

Buyrukoğlu, S. ve Erasa, İ. (2012). Vergi Bilincinin Oluşmasında Mükellef Haklarının Yeri ve Önemi, Vergi Dünyası Dergisi, Sayı: 375, 116-127.

Csontos, L., Kornai, J. ve Toth, I.G. (1998). Tax Awareness and Reform of the Welfare State: Hungarian Survey Results, Economics of Transition, Vol 6, 278-312.

Durmuş, B., Yurtkoru, S. ve Çinko, M. (2010). Sosyal Bilimlerde SPSS'le Veri Analizi, İstanbul: Beta Basım.

Egeli, H. ve Diril, F. (2014). Vergi Bilincinin Oluşumunda Bilişim Teknolojilerinin Rolü: İzmir İli İçin Bir Uygulama, Sosyo-Ekonomi Dergisi, Sayı 2, 34-56.

Güner, Ü. (2008). Türkiye'de Vergi Bilincinin ve Vergi Ahlakının Oluşmasında Gelir İdaresinin Rolü, Dokuz Eylül Üniversitesi Sosyal Bilimler Enstitüsü, (Yüksek Lisans Tezi), İzmir.

Hasseldine, J. and Hite, P.A. (2003). Framing, Gender and Tax Compliance, Journal of Economic Psychology, Vol 24, 517-553.

Hastuti, R. (2014). Tax Awareness and Tax Education: A Perception of Potential Taxpayers, International Journal of Business, Economics and Law, Vol 5, Issue 1, 83-91.

Hazman, G.G. (2009). Vergi Bilincini Etkileyen Muhtemel Dişsal Etkenlerin Lojistik Regresyon Analizi ile Tespiti, Akademik Incelemeler Dergisi, Sayı 4, Cilt 1, 54-71.

Hofmann, E., Hoelzl, E. and Kirchler, E. (2008). Preconditions of Voluntary Tax Compliance: Knowledge and Evaluation of Taxation, Norms, Fairness, and Motivation to Cooperate, Zeitschrift Fur Psychologie, Vol 216, Issue 4, 209-217. http://doi.org/10.1027/0044$\underline{3409.216 .4 .209},(11.12 .2017)$.

Kintanar, Jr. A. (1964). On the Tax Consciousness, The Philippine Review of Business and Economics, Vol 1, Issue 1, 17-30. 
Kline, P. (1994). An Easy Guide to Factor Analysis, New York: Routledge.

Maciejovsky, B., Kirchler, E. and Schwarzenberger, H. (2007). Misperception of Chance and Loss Repair: On the Dynamics of Tax Compliance, Journal of Economic Psychology, Vol 28, 678-691.

Muhasebat Genel Müdürlüğü (2017). Genel Bütçeli İdareler Bütçe Denge Tablosu, https://www.muhasebat.gov.tr/content/duyuru/genel-butceli-idareler-butce-denge-tablosu/ $\underline{179278}(12.06 .2017)$.

OECD (2017). Government at a Glance 2017, Paris: OECD Publishing. http://dx.doi.org/10.1787/gov_glance-2017-en, (16.07.2017).

Palil, M.R., Al-Maghrebi, M.S. and Ahmad, R. (2016). Budget Transparency and Tax Awareness towards Tax Compliance: A Conceptual Approach, South East Asia Journal of Contemporary Business, Economics and Law, Vol 10, Issue 1, 95-101.

Ömürbek, N., Çiçek, H.G. ve Çiçek, S. (2007). Vergi Bilinci Üzerine Bir İnceleme: Üniversite Öğrencileri Üzerinde Yapılan Anketin Bulguları, Maliye Dergisi, Sayı 153, 102-122.

Özkan, Y. (2007). Uygulamalı İstatistik 2, Sakarya: Sakarya Yayıncılık.

Sürmen, Y. (1992). Vergi Bilincinin Geliştirilmesinde Muhasebecinin Rolü, Sayıştay Dergisi, Say1 7, 25-29.

Torgler, B. (2004). Tax Morale, Trust and Corruption: Empirical Evidence from Transition Countries, Center for Research in Economics, Management and the Arts (CREMA), Working Paper, Vol 5, 3-24.

Torgler, B., Friedrich, S. and Schaltegger, C.A. (2008). Local Autonomy, Tax Morale and the Shadow Economy, Center for Research in Economics, Management and the Arts (CREMA), Working/Discussion Paper, Vol: 243, 2-40.

Yeşilyurt, Ş. (2015). Vergi Bilincinin Vergi Ahlakı Üzerinde Etkisi: Maliye ve İlahiyat Bölümü Öğrencileri Örneği, Mustafa Kemal Üniversitesi Sosyal Bilimler Enstitüsü Dergisi, Sayı 12, Cilt 32, 36-56. 